\title{
Suitability studies of different milk proteins for supplementation in functional extruded snack
}

\author{
Upasana Yadav $^{1}$, RRB Singh $^{2}$, Karnika Prakash $^{3}$, Shalini Arora ${ }^{4}$ and Alok Chatterjee ${ }^{5}$
}

Received: 14 June 2020 / Accepted: 23 July 2020 / Published online: 27 October 2020

(C) Indian Dairy Association (India) 2020

\begin{abstract}
Carbohydrate based snacks clubbed with frying have substantial dominance on Indian snack market, depriving nutrition. But awareness for alternative healthier snacks has already attracted market attention. In the present study, an effort was ventured by utilizing the combined benefits of high carotene sweet potato flour, barley flour, rice flour and milk protein (Whey Protein Concentrate (WPC)-70/ Skim Milk Powder (SMP)/ rennet casein) to design a low fat-high protein, crisp snack by extrusion cooking. The conditions employed for snack processing were the temperature of heater $1\left(110^{\circ} \mathrm{C}\right)$ and $2\left(40^{\circ} \mathrm{C}\right)$, screw speed $(370 \mathrm{rpm})$ and die diameter $(4 \mathrm{~mm})$. The effect of different proteins and their levels on snack quality were evaluated by physical and sensory responses like hardness $(\mathrm{N}), \mathrm{L}^{*}, \mathrm{a}^{*}$ and $\mathrm{b}^{*}$ color values, expansion index (EI) and sensory scores (color and appearance, flavor, texture and overall acceptability). The results revealed that addition of SMP at different rate did not showed significant $(p>0.05)$ effect on expansion index, color \& appearance and flavor score of the snack. Whereas, incorporating rennet casein as a source of quality protein, EI increased significantly $(p<0.05)$ at $15 \%$ and there was a significant effect on the sensory parameters
\end{abstract}

\footnotetext{
${ }^{1}$ Manav Rachna International Institute of Research and Studies, Faridabad, Haryana, India

${ }^{2}$ ICAR-National Dairy Research Institute, Karnal, Haryana

${ }^{3}$ Centre for Rural Development, Indian Institute of Technology, New Delhi

${ }^{4}$ Lala Lajpat Rai University of Veterinary and Animal Sciences, Hisar, Haryana

${ }^{5}$ Global Design, SPX Flow (India) Pvt. Ltd.

Upasana Yadav $(\triangle)$

Department of Nutrition and Dietetics, Manav Rachna International Institute of Research and Studies, Faridabad- 121004, Haryana, India

E-mail: upasana.ndri@gmail.com, upasana.fas@mriu.edu.in
}

with increasing rennet level. However, increasing WPC-70 addition, the EI and sensory scores declined, and the hardness of the snack increased. Highest EI (3.18) and sensory scores were observed at $15 \%$ level of casein. From quantified parameters, casein was deduced to be most acceptable milk protein source for the intended snack.

Keywords: Composite flour, Extruded snacks, Functional food, Milk proteins, Physical properties

\section{Introduction}

Extrusion is a HTST technology that combines several unit operations comprising mixing, cooking, kneading, shearing, shaping, and forming (Steel et al. 2012). This process gelatinizes starch, denatures proteins, modifies lipids, and inactivates enzymes, microbes, and antinutritional factors (Singh, Gamlath and Wakeling 2007).The worldwide demand of extruded snack foods is high as they are available in variety of shapes, textures, colours and flavours. However, extruded snacks are typically high in calories and fat with low content of protein, fibre, and perceived as unhealthy or junk food to many consumers (Korkerd et al. 2016; Basto et al. 2016). A possible solution to this problem is incorporation of alternative ingredients like fruits and vegetables, banana powder, legume flour, oats and whole grains etc. in extruded product preparations to enhance their nutritional quality (Sukumar and Athmaselvi, 2019; Oliveira et al. 2018). However, many researchers have observed that addition of dietary fibre often leads to lower expansion volumes, higher density, harder texture, less crispness, and thus reducing the acceptability of the extruded snack (Veronica et al. 2006; Brennan et al. 2008; Robin et al. 2011; Chanvrier et al. 2013; Chassagne-Berces et al. 2011).

Milk proteins are recognized for their nutritive and health benefits (Zimecki and Kruzel 2007). These proteins have many biological activities: cancer prevention, tumour cell vulnerability increase, antimicrobial activities and immunomodulation (Madureira et al. 2007). Milk proteins have good digestibility (Hambraeus, 1992), as well as Protein Efficiency Ratio (PER), whey protein and caseins have a PER of 3.2 and 2.6, respectively (Walzem et al. 2002). Lately, milk constituents have been acclaimed as functional foods, 
as they impart numerous therapeutic benefits which improve health. Use of dairy proteins in cereal based products, improves the nutrient density of extruded snacks by increasing protein and mineral content (Brncic et al. 2011; Pordesimo et al. 2009). Attempts have been made to use whey protein concentrates or dried whey for extrusion purpose (Onwulata and Konstance, 2006; Onwulata et al. 2010; Fernandes et al. 2016; El-Ghany, et al. 2013; Chaudhari et al. 2020). The type and level of milk protein incorporated into an extrudate affects the water holding capacity, nitrogen solubility index and sorption characteristics of extruded products (Allen et al. 2007). This study was focused on combining different milk proteins (Skim milk powder/ whey protein concentrate-70/ rennet casein) with composite flour (sweet potato, barley and rice) to enhance the nutritional status of extruded snack and evaluate the effect of level and type of these milk proteins on physical and sensorial properties, that would ultimately have an effect on acceptability of the product by the consumer in market.

\section{Materials and Methods}

\section{Raw Materials}

Carotene rich variety of sweet potato, Indramadhur was purchased from Regional Centre of Central Tuber Crop Research Institute (CTCRI), Bhubaneswar, Odisha. Barley (DWRB-73 variety) was procured from the Directorate of Wheat Research (DWR), Karnal, Haryana. Paddy (PR-44) was procured from Indian Agricultural Research Institute (IARI- Regional Centre), Karnal, Haryana. Milk Protein Sources (WPC-70, Rennet Casein and SMP) were procured from M/s Modern Dairies Ltd., Karnal, Haryana. Sweet potatoes were washed, sliced, dipped in $0.1 \%$ $\mathrm{KMS}$ solution for $5 \mathrm{~min}$ and then dried in tray drier at $60^{\circ} \mathrm{C}$ for 4 $5 \mathrm{hr}$. The dried slices were then ground to fine powder. Barley and paddy were de-husked, cleaned and then subjected to milling.

\section{Proximate analysis of the raw material}

Standard procedures as described in AOAC (2000) were used for proximate analysis of sweet potato, barley and rice flour and skim milk protein, casein, and WPC-70 (Moisture, protein, crude fat and ash content).

\section{Preparation of composite extruded snack}

Based on preliminary trials, the composite flour ratio (sweet potato, barley and rice flour) were fixed at 20, 25 and 30 parts, respectively. The three types of milk protein (WPC-70, SMP and rennet casein) used for the study were at proportion of 5, 10 and 15 parts. The methodology adopted was as described by Yadav et al. 2016. The ingredients were blended in a Hobart mixer at 60 rpm, moisture was adjusted to $12 \%$ and the blend was passed through $2 \mathrm{~mm}$ size sieve and again blended for $10 \mathrm{~min}$. to get uniform mixing. The premix was packed in $1 \mathrm{~kg}$ PE bag and preconditioned overnight in a refrigerator before extruding using twin-screw extruder. The speeds of feeder screw and extruder screw were kept constant at 40 and $370 \mathrm{rpm}$, respectively. The temperature of the two heating zones were $40^{\circ} \mathrm{C}$ and $120^{\circ} \mathrm{C}$, respectively. As the material was extruded through $4 \mathrm{~mm}$ die and was cut into pieces of desired length by a rotating-blade cutter at $10 \mathrm{rpm}$. Extrudates were then packed in metalized PE pouches and stored at $37^{\circ} \mathrm{C}$ until further analysis.

\section{Sensory evaluation}

Sensory evaluation was conducted by 10 trained panelists from NDRI, Karnal. Product evaluation was based on its color \& appearance, flavor, texture, and overall acceptability on 9-point hedonic scale $(1=$ dislike extremely to $9=$ like extremely) (Deshpande and Poshadri, 2011).

\section{Hardness (Texture Analysis)}

Hardness is the peak force during compression of the product. It was determined using TA-XT2i (Stable Micro Systems, UK) Texture Analyzer fitted with a $25 \mathrm{~kg}$ load-cell and Warner-Bratzler Blade. The pre-test and post-test speed were $2.0 \mathrm{~mm} / \mathrm{sec}$, while the test speed was $1.0 \mathrm{~mm} / \mathrm{sec}$.

\section{Expansion ratio}

The ratio of diameter of extrudate and the diameter of die was used to express the radial expansion of extrudate (Fan et al., 1996). The extrudate expansion ratio was calculated as follows:

$$
\text { Expansion ratio }=\frac{\text { Extrudate diameter }(\mathrm{mm})}{\text { Die diameter }(\mathrm{mm})}
$$

\section{Hunter color analysis}

The color of the product was measured using a Hunter Lab Colour flex colourimeter (Hunter Associated Laboratory, Inc., USA) using the Universal software version 4.10. Measurement was made by taking finely ground sample in the glass sample holder up to $2 \mathrm{~cm}$ height followed by tapping for ten times on bench-top. Data were received through the software in terms of $\mathrm{L}^{*}$ (lightness), ranging from zero (black) to 100 (White), $\mathrm{a}^{*}$ (Redness), +60 (red) to -60 (green) and $b^{*}$ (yellowness), ranging from +60 (yellow) to -60 (blue) values of the international (CIE) color system.

\section{Statistical analysis}

The data obtained from the given experiments for milk protein sources incorporation in composite extruded snack were subjected to analysis using two-way ANOVA using SPSS Statistical tool (version 20, IBM Corp., New York, NY, USA) as described by Snecdecor and Cocharan (1994). The data were presented as Means \pm Standard Error (SE). 


\section{Results and Discussion}

\section{Proximate analysis}

The results obtained for proximate analysis of raw material are presented in Table 1. It is evident, that rennet casein had highest crude protein content i.e. $80.16 \%$, followed by WPC-70 $(69.70 \%)$ whereas, sweet potato flour (SPF) had the least amount of proteins $(1.05 \%)$. The fat content in rice flour was least with the value being $0.45 \%$ and highest fat content was observed in WPC-70 i.e. $4.66 \%$. Casein and SMP had high percentage of ash content ( 7.94 and $7.89 \%$, respectively) whereas barley and rice flours had lower levels ( 1.55 and $0.45 \%$ ). The carbohydrate content of the flours was calculated by subtracting percentage of all other components from 100. Similar values of proximate analysis of milk proteins was reported by Ponbhagavathi et al. (2018)

\section{Hunter color values of raw materials}

The color of the raw material has a prominent effect on the appearance of the processed product, thereby effecting its consumer acceptability. The $\mathrm{L}^{*}$ value was found to be maximum with Skim milk powder (92.03), thus indicating that SMP was the brightest and whiter among all the ingredients (Table 2). The lowest $\mathrm{L}^{*}$ value was observed for SPF (72.61) but a* and $\mathrm{b}^{*}$ values were highest for SPF indicating that it was darker compared to other raw materials.

\section{Effect of incorporation of milk proteins on expansion index and hardness}

A higher value of expansion index in extruded snacks represent a product with greater crispiness and less dense structure. The composition of the raw ingredients has a significant effect on the expansion. During extrusion the high temperature and shear, gelatinize the starch forming a matrix with entrapped water molecules, due to sudden pressure drop at the exit, expansion of the extrudate occurs as the water molecules expand forming bubbles and creating a porous structure (Guy and Horne, 1988). When raw material have higher amounts of protein and/ or fibre, the starch level drops, resulting in lesser expansion and increased density. The values of expansion index and hardness are represented in Table 3 . The values ranged from a lowest of 1.68 (15\% WPC 70$)$ to 3.18 (15\% rennet casein). SMP did not have have any significant difference with increase in level, while in case of WPC, the E.I. decreased tremendously with increase in level from 5 to $15 \%$. Ding et al. (2005) reported values between 2.02 and 3.87 for rice-based extrudates. It is evident from the table that increasing level of SMP did not have any significant effect on E.I. of extrudates, whereas in case of rennet casein, E.I. increased significantly ( $\mathrm{p}$ d" 0.01 ) as the level increased from 5 to $15 \%$. Patel et al. (2016) also observed that the increasing level of rennet casein resulted in a significant increase in the expansion ratio $(\mathrm{p}<0.05)$. This may be due to the large molecular structure of casein, hydrophobic properties and random coil conformation in comparison to whey protein concentrate and isolate (Onwulata and Konstance 2006). However, an opposite trend was observed in case of WPC-70, as the level of incorporation was increased, there was reduction in the expansion of the snack. Reduction in expansion with increasing whey protein concentration as a result of starch-protein interactions was reported by Allen et al. (2007). Another study conducted by Chinnaswamy and Hanna (1988) also concluded that there was decrease in the expanded volume of cereal flour-based snacks when level of lipid and protein is increased in the mixture.

Table 1 Proximate composition (g/ 100g) of raw materials used for extruded snack preparation

\begin{tabular}{llllll}
\hline Constituent & Moisture & Crude protein & Fat & Carbohydrate* & Total ash \\
\hline SPF $^{\#}$ & $5.94 \pm 0.36$ & $1.05 \pm 0.45$ & $0.69 \pm 0.05$ & 88.93 & $3.38 \pm 0.03$ \\
Barley Flour & $5.63 \pm 0.18$ & $14.97 \pm 0.00$ & $1.68 \pm 0.11$ & 76.17 & $1.55 \pm 0.00$ \\
Rice Flour & $11.22 \pm 0.22$ & $8.40 \pm 0.45$ & $0.45 \pm 0.19$ & 79.48 & $0.45 \pm 0.042$ \\
Casein & $8.90 \pm 0.04$ & $80.16 \pm 0.44$ & $0.96 \pm 0.04$ & - & $7.94 \pm 0.021$ \\
WPC-70\% & $3.76 \pm 0.27$ & $69.70 \pm 0.46$ & $4.66 \pm 0.05$ & - & $3.89 \pm 0.197$ \\
SMP & $3.8 \pm 0.48$ & $34.05 \pm 0.44$ & $1.2 \pm 0.31$ & 53.06 & $7.89 \pm 0.003$ \\
\hline
\end{tabular}

*By difference; ${ }^{\#}$ Sweet potato flour; Values are mean \pm standard error $(n=3)$

Table 2 Hunter color parameters (L, a, b values) of raw materials

\begin{tabular}{llll}
\hline Constituent & \multicolumn{3}{c}{ Hunter color parameters } \\
\cline { 2 - 4 } & L*value & $\mathrm{a}^{*}$ value & $\mathrm{b}^{*}$ value \\
\hline SPF & $72.61 \pm 0.32$ & $4.31 \pm 0.09$ & $20.65 \pm 0.38$ \\
Barley flour & $81.52 \pm 0.14$ & $1.43 \pm 0.27$ & $9.15 \pm 0.04$ \\
Rice flour & $86.71 \pm 0.23$ & $-0.01 \pm 0.02$ & $6.51 \pm 0.02$ \\
Rennet Casein & $83.03 \pm 0.11$ & $-0.64 \pm 0.05$ & $10.98 \pm 0.02$ \\
WPC-70\% & $84.55 \pm 0.16$ & $0.92 \pm 0.13$ & $20.68 \pm 0.21$ \\
SMP & $92.03 \pm 0.01$ & $-3.02 \pm 0.04$ & $16.71 \pm 0.02$ \\
\hline
\end{tabular}

Values are mean $\pm \mathrm{SE}(\mathrm{n}=5)$ 
Hardness is the peak force required for a probe to penetrate or break the extrudate (Ponbhagavathi et al. 2018). Expansion index and the cell structure of the extruded snack have an impact on the hardness. The values ranged from $21.51 \mathrm{~N}$ to $54.13 \mathrm{~N}$, the highest value was observed for $15 \%$ WPC 70 . When extrudate was made with incorporation of skim milk powder, the hardness of the product reduced from $25.64 \mathrm{~N}$ to $21.72 \mathrm{~N}$. There was no significant change $(\mathrm{p}>0.05)$ in the hardness values when extrudate was made with incorporation of rennet casein. It was reported by Voort and Stanley (1984), that there was no significant effect on hardness value of wheat flour extrudates by incorporation of rennet casein (10 to $30 \%$ ). Another study concluded that rennet casein, tended to decrease the hardness at lower levels, but the effect was not significant at higher levels (Patel et al. 2016). When WPC 70 was added to the ingredient mix as the milk protein source, the hardness of the product increased significantly $(\mathrm{p}<0.01)$ from $28.69 \mathrm{~N}(5 \%)$ to $54.13 \mathrm{~N}(15 \%)$. It is evident that hardness level increased with increase in level of WPC 70. Similar results were obtained by Yadav et al. (2013), in pearl millet-WPC extruded snacks. This may be due to fact that the protein competes with the starch for the water during extrusion, reducing the rate of gelatinization and thereby

Table 3 Physical properties of composite flour based extruded snack affected by different milk proteins

\begin{tabular}{lllll}
\hline Physical Properties & Level $(\%)$ & \multicolumn{3}{l}{ Milk Protein Type $^{\#}$} \\
\cline { 2 - 4 } & & SMP & Rennet Casein & WPC-70 \\
\hline Hardness & 5 & $25.64^{\mathrm{bB}} \pm 0.55$ & $22.27^{\mathrm{aA}} \pm 0.73$ & $28.69^{\mathrm{aC}} \pm 1.53$ \\
& 10 & $27.35^{\mathrm{cB}} \pm 0.09$ & $21.51^{\mathrm{aA}} \pm 1.08$ & $35.22^{\mathrm{bC}} \pm 2.61$ \\
Expansion Index & 15 & $21.72^{\mathrm{aA}} \pm 0.12$ & $22.26^{\mathrm{aA}} \pm 0.13$ & $54.13^{\mathrm{cB}} \pm 1.42$ \\
& 5 & $2.403^{\mathrm{aA}} \pm 0.21$ & $2.91^{\mathrm{aB}} \pm 0.04$ & $2.91^{\mathrm{cB}} \pm 0.19$ \\
& 10 & $2.49^{\mathrm{aA}} \pm 0.12$ & $2.87^{\mathrm{aB}} \pm 0.02$ & $2.32^{\mathrm{bA}} \pm 0.13$ \\
L value & 15 & $2.39^{\mathrm{aB}} \pm 0.10$ & $3.18^{\mathrm{bC}} \pm 0.18$ & $638^{\mathrm{aA}} \pm 0.02$ \\
& 5 & $62.25^{\mathrm{aA}} \pm 1.58$ & $65.46^{\mathrm{bB}} \pm 0.30$ & $65.62^{\mathrm{bC}} \pm 0.29$ \\
& 10 & $64.55^{\mathrm{bB}} \pm 0.13$ & $64.05^{\mathrm{aA}} \pm 0.14$ & $68.79^{\mathrm{cC}} \pm 0.23$ \\
a value & 15 & $64.98^{\mathrm{bB}} \pm 0.09$ & $64.45^{\mathrm{aA}} \pm 0.12$ & $7.60^{\mathrm{cB}} \pm 0.31$ \\
& 5 & $8.18^{\mathrm{aB}} \pm 0.56$ & $5.59^{\mathrm{aA}} \pm 0.67$ & $5.69^{\mathrm{bA}} \pm 0.73$ \\
& 10 & $7.40^{\mathrm{aB}} \pm 0.31$ & $7.71^{\mathrm{bB}} \pm 0.57$ & $4.71^{\mathrm{aA}} \pm 0.30$ \\
b value & 15 & $7.54^{\mathrm{aB}} \pm 0.22$ & $7.52^{\mathrm{bB}} \pm 0.50$ & $24.93^{\mathrm{cA}} \pm 0.54$ \\
& 5 & $25.02^{\mathrm{aA}} \pm 0.33$ & $25.25^{\mathrm{aA}} \pm 0.51$ & $23.37^{\mathrm{bA}} \pm 0.44$ \\
& 10 & $24.79^{\mathrm{aB}} \pm 0.14$ & $25.05^{\mathrm{aB}} \pm 0.56$ & $20.34^{\mathrm{aA}} \pm 0.25$ \\
\hline
\end{tabular}

\#Milk Protein Type: SMP-Skim milk powder, WPC-70- whey protein concentrate

abc; ${ }^{A B C}$ Means \pm S.E. $(n=15)$ with same superscripts in a row $(A, B, C)$ or in a column (a, b, c) do not differ signiûcantly (P d" 0.01$)$.

Table 4 Sensory scores of composite flours based extruded snack affected by different milk proteins

\begin{tabular}{lllll}
\hline Sensory Attribute* & Level $(\%)$ & \multicolumn{3}{c}{ Milk Protein Type $^{\#}$} \\
\cline { 2 - 4 } & & SMP & Rennet Casein & WPC-70 \\
\hline Color \& appearance & 5 & $5.93^{\mathrm{aA}} \pm 0.58$ & $6.87^{\mathrm{bB}} \pm 0.08$ & $6.49^{\mathrm{cAB}} \pm 0.06$ \\
& 10 & $6.69^{\mathrm{aB}} \pm 0.27$ & $6.43^{\mathrm{aB}} \pm 0.04$ & $5.84^{\mathrm{bA}} \pm 0.10$ \\
Flavor & 15 & $6.80^{\mathrm{aB}} \pm 0.44$ & $7.50^{\mathrm{cC}} \pm 0.20$ & $6.20^{\mathrm{aA}} \pm 0.13$ \\
& 5 & $5.98^{\mathrm{aA}} \pm 0.51$ & $6.83^{\mathrm{aB}} \pm 0.14$ & $5.78^{\mathrm{bA}} \pm 0.49$ \\
& 10 & $6.44^{\mathrm{aA}} \pm 0.17$ & $6.26^{\mathrm{aA}} \pm 0.41$ & $4.36^{\mathrm{aA}} \pm 0.32$ \\
Texture & 15 & $6.73^{\mathrm{aB}} \pm 0.36$ & $7.67^{\mathrm{bC}} \pm 0.08$ & $6.29^{\mathrm{cAB}} \pm 0.53$ \\
& 5 & $5.65^{\mathrm{aA}} \pm 0.78$ & $7.03^{\mathrm{bB}} \pm 0.19$ & $5.47^{\mathrm{bA}} \pm 0.18$ \\
Overall Acceptability & 10 & $6.77^{\mathrm{bB}} \pm 0.19$ & $6.77^{\mathrm{aB}} \pm 0.11$ & $4.05^{\mathrm{aA}} \pm 0.41$ \\
& 15 & $6.93^{\mathrm{bB}} \pm 0.04$ & $7.54^{\mathrm{cC}} \pm 0.09$ & $6.17^{\mathrm{cA}} \pm 0.40$ \\
& 5 & $5.88^{\mathrm{aA}} \pm 0.77$ & $6.83^{\mathrm{bA}} \pm 0.06$ & $5.49^{\mathrm{bA}} \pm 0.18$ \\
& 10 & $6.64^{\mathrm{abB}} \pm 0.06$ & $6.53^{\mathrm{aB}} \pm 0.13$ & $4.12^{\mathrm{aA}} \pm 0.16$ \\
\hline
\end{tabular}

*On a 9-point hedonic rating scale: 9-like extremely; 1-dislike extremely.

"Milk Protein Type: SMP- Skim milk powder, WPC-70- whey protein concentrate

abc; $A B C$ Means \pm S.E. $(n=10)$ with same superscripts in a row $(A, B, C)$ or in a column $(a, b, c)$ do not differ signiûcantly (P d" 0.01$)$. 
decreasing expansion and increasing hardness of the product. In addition, the higher amounts of protein may also result in variation in temperature and pressure inside the extruder, affecting the degree of expansion and textural properties (Anton et al. 2009; Sumargo et al. 2016). Anton and Luciano (2007) also stated that the extrudates hardness depends on raw material composition, as well as feed moisture and extrusion conditions. Protein rich extrudates produce less expandable products and more rigid network resulting in higher resistance to shear and lower expansion (Li et al., 2005).

\section{Effect of incorporation of milk proteins on colour parameters}

Food acceptability is affected by color of the product. It acts as an indicator of quality, flavor expectation and commercial value (Fradique et al., 2010). Color of an extrudate is an indicator of thermal history and account of non-enzymatic browning resulting from maillard browning during extrusion process (Yadav et al. 2013). The $L^{*}, a^{*}$ and $b^{*}$ value of extruded snack as effected by type and level of milk protein is presented in table 3 . The $\mathrm{L}^{*}$ values for extrudates ranged from 62.25 to 68.79 . The $\mathrm{L}^{*}$ value was highest in case of WPC 70, indicting a lighter product in comparison to SMP and rennet casein. Positive $b^{*}$ values indicate the yellowness of a sample and negative values are indicative of a blue color. As the extruded snack had sweet potato flour rich in soluble sugars, the $b^{*}$ value was on higher side (20.34 for WPC to 25.63 for SMP). Non-enzymatic browning reactions like caramelisation and the Maillard reactions forms compounds that have higher a* value (Ilo and Berghofer 1999). Melanoidins formed in the Maillard reaction impart a darker colour to extrudates. Process conditions during extrusion, high lactose content and protein content in whey powder also intensify the dark color of these compounds (Tamanna and Mahmood, 2015).

\section{Effect of incorporation of milk proteins on sensorial properties}

The consumer acceptance of any product depend on the sensorial properties of the product. The sensory properties like colour, flavour, texture, and overall acceptability were significantly $(\mathrm{p}<0.01)$ affected by the level and type of milk protein incorporated (table 4). The lowest score (4.90) for colour and appearance was observed for $15 \%$ WPC 70 while highest (7.50) was observed for rennet casein $15 \%$. The scores improved with increase in level of SMP and rennet casein from 5 to $15 \%$, whereas the values decreased in case of increment of WPC 70. More or less similar trend was also noticed for flavour, texture and O.A. scores of the extruded snack. On comparison of different protein sources, it can be observed that rennet casein at 15\% level, had significantly higher scores $(\mathrm{p}<0.01)$ in all sensory parameters compared to SMP and WPC 70. Higher acceptability in case of rennet casein incorporation maybe attributed to higher expansion and crisp texture of the extruded snack.

\section{Conclusions}

The study indicated that types and levels of milk proteins had a significant $(p<0.01)$ effect on the hardness, expansion index and color values of the extruded snack. The sensory scores were significantly affected by the type of milk protein used to make high protein extruded snack. Rennet casein had better acceptability as depicted by the trained sensory panelist compared to product prepared with incorporation of WPC. The snack prepared using 5\% level of WPC was acceptable but at higher levels (10\% and $15 \%)$, the overall quality of the snack declined extremely. Increasing level of SMP didn't show significant effect on the sensory and physical parameters. Significant improvement in the expansion index and sensory scores of extruded snack with rennet casein was observed at all levels. Thus, a highly acceptable, high protein product with desirable physical, sensory characteristics could be prepared with rennet casein as a source of quality protein.

\section{Acknowledgements}

The corresponding author is thankful to The Director, National Dairy Research Institute for providing infrastructural amenities and Department of Science and Technology, New Delhi for economic assistance in the form of INSPIRE Fellowship for conducting the presented research work.

\section{References}

Allen KE, Carpenter CE, Walsh MK (2007) Influence of protein level and starch type on an extrusion-expanded whey product. Int $\mathrm{J}$ of Food Sc Technol 42: 953-960

Anton AA, Fulcher RG, Arntfield SD (2009) Physical and nutritional impact of fortification of corn starch-based extruded snacks with common bean (Phaseolus vulgaris L.) flour: effects of bean addition and extrusion cooking. Food Chem 113: 989- 996 http://dx.doi.org/ 10.1016/j.foodchem.2008.08.050.

Anton AA, Luciano FB (2007) instrumental texture evaluation of extruded snack foods: a review. Cienc. Tecnol. Aliment 5: 245-251

AOAC (2000) Official Method of Analysis, Association of Official Analytical Chemist, 16th Edn., Washington DC

Basto GJ, Carvalho CWP, Soares AG, Costa HTGB, Chaìvez DWH, Godoy RLD, Pacheco S (2016). Physicochemical properties and carotenoid content of extruded and non-extruded corn and peach palm (Bactris gasipaes, Kunth). LWT - Food Sc Technol 69: 312-318 http:// dx.doi.org/10.1016/j. lwt.2015.12.065.

Brennan MA, Monro JA, Brennan CS (2008) Effect of inclusion of soluble and insoluble fibres into extruded breakfast cereal products made with reverse screw configuration. Int $\mathrm{J}$ of Food Sc Technol 43: 2278-2288

Brncic M, Bosiljkov T, Ukrainczyk M, Tripalo B, Brncic SR, Karlovic S, Topic DV (2011) Influence of whey protein addition and feed moisture content on chosen physicochemical properties of directly expanded corn extrudates. Food Bioprocess Technol 4: 1296-1306

Chanvrier H, Desbois F, Perotti F, Salzmann C, Chassagne S, Gumy JC, Blank I (2013) Starch-based extruded cereals enriched in fibers: A behavior of composite solid foams. Carbohydr Polym 98: 842-853 DOI: 10.1016/j.carbpol.2013.07.005 
Chassagne-Berces S, Leitner M, Melado A, Barreiro P, Correa EC, Blank I, Gumy JC Chanvrier H (2011) Effect of fibers and whole grain content on quality attributes of extruded cereals. Procedia Food Sc 1: 17-23 https://doi.org/10.1016/j.profoo.2011.09.004

Chinnaswamy R, Hanna MA (1988) Expansion, color and shear strength properties of corn starches extrusion-cooked with urea and salts. Starch 40: 186-190

Chaudhari BB, Patel AM and Smitha B (2020) Sensory, physico-chemical, microbial and textural changes in whey protein concentrate based extruded snack food during storage. Int J Chem Stud 8: 2736-2740. DOI: 10.22271/chemi.2020.v8.ilap.8684

Deshpande HW, Poshadri A (2011) Physical and sensory characteristics of extruded snacks prepared from foxtail millet-based composite ours. International Food Research Journal 18: 751-756Gaspar MCMP, Soares RAM, Cardenas TC, Lima SCTC, Areas JAG (2012) Extrusion, storage and $\beta$-carotene stability of snacks. Aliment. e Nutrição 23: 529-535

Ding QB, Ainsworth P, Tucker G, Marson H (2005)The effect of extrusion conditions on the physicochemical properties and sensory characteristics of rice-expanded snacks. J Food Eng. 66: 283-289 doi: 10.1016/j.jfoodeng.2004.03.019.

El-Ghany IHA, El-Asser MA, Nagy KS, El-Maksoudm AAA (2013) Effect of milk proteins on physical and chemical characteristics of crispy puff snacks. J Agrc Sci Technol A3: 633-645

Fan J, Mitchell JR, Blanchard JMV (1996) The effect of sugars on the extrusion of maize grits: The role of the glass transition in determining product density and shape. Int J Food Sc Technol 31: $55-65$.

Fernandes AF, Madeira RAV, Carvalho CWP, Pereira J (2016) Physical and sensory characteristics of pellets elaborated with different levels of corn grits and whey protein concentrate. Sci Agrotechnol 40: $235-243$

Fradique M, Batista AP, Nunes MC, Gouveia L, Bandarra NM, Raymundo A (2010) Incorporation of Chlorella vulgaris and Spirulina maxima biomass in pasta products. Part 1: preparation and evaluation. J Sci Food Agric 90: 1656-1664. PMid:20564448. http://dx.doi.org/ $10.1002 /$ jsfa.3999.

Guy RCE, Horne AW (1988) Extrusion and co extrusion of cereals. In: Food Structure: Its Creation and Evaluation; Blanshard, J.M.V.; Mitchell, J.R.; Eds.; Butterworths: London, 331

Hambraeus (1992) Nutritional aspects of milk proteins. In: Fox PF (ed) Advanced dairy chemistry. Vol. 12nd edn. Elsevier Applied Science.

Ilo S, Berghofer E (1999) Kinetics of colour changes during extrusion cooking of maize grits. J Food Eng 39: 73-80

Korkerd S, Wanlapa S, Puttanlek C, Uttapap D, Rungsardthong V (2016) Expansion and functional properties of extruded snacks enriched with nutrition sources from food processing by-products. J Food Sci Technol 53: 561-570 DOI 10.1007/s13197-015-2039-1

Li SQ, Zhang HQ, Tony JZ, Hsieh FH (2005) Textural modification of soya bean/corn extrudates as affected by moisture content, screw speed and soya bean concentration. Int J of Food Sc Technol 40: 731-741

Madureira AR, Pereira CI, Gomes AMP, Intado ME, Malcata FX (2007) Bovine whey proteins - Overview on their main biological properties. Food Res Int 40: 1197-1211 DOI: 10.1016/ j.foodres.2007.07.005.

Oliveira LC, Alencar NMM, Steel CJ (2018) Improvement of sensorial and technological characteristics of extruded breakfast cereals enriched with whole grain wheat flour and jabuticaba (Myrciaria cauliflora) peel. LWT - Food Sci Technol 90: 207-214

Onwulata CI (2010) Use of extrusion-texturized whey protein isolates in puffed corn meal. J Food Process Pres 34: 571-586
Onwulata CI, Konstance RP (2006) Extruded corn meal and whey protein concentrate: effect of particle size. J Food Process Pres 30: 475487

Patel J, Patel AA, Singh AK (2016) Production of a protein-rich extruded snack base using tapioca starch, sorghum flour and casein. J Food Sci Technol 53: 71-87. DOI 10.1007/s13197-015-2012-z

Ponbhagavathi TRTM, Singh AK, Raju PN, Arora S, Meena GS, Borad S (2018) Effect of extrusion processing parameters on hardness and crispiness of milk protein-maize based extrudates Int J Chem Stud 6:1656-1658

Pordesimo LO, Onwulata CI, Carvalho WP (2009) Food Powder Delivery Through a Feeder System: Effect of Physicochemical Properties, Int J Food Prop 12: 556-570 DOI: 10.1080/10942910801947748

Robin F, Dubois C, Curti D, Schuchmann HP, Palzer S (2011). Effect of wheat bran on the mechanical properties of extruded starchy foams. Food Res Int 44: 2880-2888

Singh S, Gamlath S, Wakeling L (2007) Nutritional aspects of food extrusion: A review. Int J Food Sci Technol 42: 916-929

Snecdecor G W and Cochran W G (1994) Statistical Methods, 6th edn, pp. 141-299. Ames, IA: The Iowa State University Press.

Steel CJ, Schmiele M, Leoro MGV, Ferreira RE, Chang YK (2012) Thermoplastic Extrusion in Food Processing, Thermoplastic Elastomers, Adel Zaki El-Sonbati, IntechOpen, 265-290 DOI: $10.5772 / 36874$.

Sukumar A, Athmaselvi KA (2019) Optimization of process parameters for the development of finger millet based multigrain extruded snack food fortified with banana powder using RSM. J Food Sci Technol 56: 705-712 https://doi.org/10.1007/s13197-018-3527-x

Sumargo F, Gulati P, Weier S A, Clarke J, Rose DJ (2016). Effects of processing moisture on the physical properties and in vitro digestibility of starch and protein in extruded brown rice and pinto bean composite flours. Food Chem 211: 726-733 PMid:27283689. http://dx.doi.org/10.1016/j.foodchem.2016.05.097.

Tamanna N., Mahmood N. (2015): Food processing and Maillard reaction products: Effect on human health and nutrition. Int J Food Sci Article ID 526762: 6 .

Veronica AO, Olusola OO, Adebowale EA (2006) Qualities of extruded puffed snacks from maize/soybean mixture. J Food Eng 29: 149161

Voort FR, Stanley DW (1984) Improved utilization of dairy proteins: coextrusion of casein and wheat flour. J Dairy Sci 67: 749-758

Walzem RL, Dillard CJ, German JB (2002) Whey components: millennia of evolution create functionalities for mammalian nutrition: what we know and what we may be overlooking. Cri Rev Food Sci Nutr J 42: $353-375$

Yadav DN, Anand T, Navnidhi, Singh AK (2013) Co-extrusion of pearl millet-whey protein concentrate for expanded snacks Int J Food Sci Technol, doi:10.1111/ijfs. 12373

Yadav U, Singh RRB, Chatterjee A (2016) Optimization of physical properties and protein to produce functional extruded snack concocted with composite flour using RSM. Indian J Dairy Sci 69: 24-32

Zimecki M, Kruzel ML (2007) Milk-derived proteins and peptides of potential therapeutic and nutritive value. J Exper Therap Onco 6: 89-106 